\section{Randomly Amplified Polymorphic DNA Analysis in the Genus Hosta}

\author{
Roger J. Sauve ${ }^{1}$ and Suping Zhou \\ Tennessee State University, 3500 J.A. Merritt Blvd. Nashville, TN 37209-1561
}

\author{
Yingchun Yu \\ Vanderbilt University, 771 Preston Building, Nashville, TN 37209
}

\author{
Wolfram George Schmid \\ 4417 Goodfellows Court, Tucker, GA 30084-2710
}

Additional index words. phylogenetic clustering, phylogenetic relationship, genetic similarity, primer

\begin{abstract}
A randomly amplified polymorphic DNA (RAPD) technique was used to identify and determine the phylogenetic relationships of 37 hosta accessions representing the major subgenera, sections and groups in the genus Hosta. Results of this study show that RAPD markers were able to differentiate not only the main groups, whose plants shared many genetic traits, but also cultivars within a species. Some accessions were identified by a single primer while others had high intercross linkage and required many markers for their separation. The phylogenetic clustering showed that $H$. plantaginea, the only night-blooming species, and $H$. ventricosa, the only known natural tetraploid, are unique and should be classified separately. The four species in the subgenus Bryocles, section Lamellatae $H$. venusta, $H$. minor, $H$. capitata, and $H$. nakaiana have very low genetic similarity since they do not share many amplified fragments. The other accessions were classified into four main clusters; cluster 1: $H$. venusta, $H$. tardiva, $H$. pycnophylla, $H$. tsushimensis 'Ogon', $H$. montana, $H$. tibae, H. montana f. macrophylla, H. kikutii 'Kikutii', H. longissima 'Longifolia', H. rectifolia 'Rectifolia', H. takahashii and $\boldsymbol{H}$. 'Undulata'; cluster 2: H. laevigata, H. sieboldiana, $\boldsymbol{H}$. pycnophylla $\times$ H. longipes $f$. latifolia, H. longipes 'Urajiro' and H. ibukiensis; cluster 3: H. capitata, H. kikutii 'Polyneuron', H. nigrescens, H. kikutii 'Yakusimensis', H. pachyscapa, H. kikutii 'Caput-Avis', H. longipes f. latifolia, H. hypoleuca, H. okamotoi, H. densa and H. takiensis; and cluster 4: H. aequinoctiiantha, $\mathrm{H}$. rupifraga, $H$. 'Amanuma', H. minor and H. kikutii 'Densa'.
\end{abstract}

The genus Hosta contains one of the most popular ornamental perennials. Members of this genus are widely used as foliage plants in shaded gardens throughout the temperate regions of the world. They are especially popular in the United States, Canada, Britain, China and Japan. Hostas or plantain lilies originated in the bordering areas between the East China Sea and the Sea of Japan where wild species are distributed in eastern China, Korea, the JapaneseArchipelago and the southern SikhoteAlin Mountains located in the eastern areas of the former USSR (Schmid, 1991). Based on their geographical distribution, hostas are divided into three subgenera (Hosta, Bryocles, Giboshi), while species are distinguished by their floral characters (Schmid, 1991). Criteria for cultivar separation are leaf and overall plant characteristics (Grenfell, 1996).

With the current classification system, it is very difficult to classify newly named interspecific hybrids and intermediate phenotypes and to determine their relationship with other

Received for publication $17 \mathrm{Dec} .2004$. Accepted for publication 27 Dec. 2004. The authors thank Chris Catanzaro and Sarabjit Bhatti at Tennessee State University for critically reviewing this manuscript. The project was financially supported by the USDA Capacity Building Grant 91-38814-6244 and by Evan-Allen funds. We gratefully acknowledge the technical support of J.T. Ling.

${ }^{1}$ To whom all correspondence should be directed; e-mail rsauve@tnstate.edu. of various ranks are still a subject of dispute. Zonneveld $(1997,1998)$ andZonneveld and Iren (2001) added two additional characteristics for taxonomic uses: genome size and pollen. Their studies showed that the nuclear DNA content and overall DNA composition between different subgenera varied. They consider low pollen viability to be an important criterion for hybrid differentiation.

In spite of these efforts, many hostas are still not easily classified. DNA fingerprinting techniques have been shown to have the potential to resolve minute genetic differences (Bielawski et al., 1995; Lin et al., 1995; Gawel et al, 1996; Ling et al., 1997; Zhou and Sauve, 2002). This study was initiated to evaluate the feasibility of randomly amplified polymorphic DNA(RAPD) for the differentiation of individual hostas and for the determination of their genetic relationship with others. The species and varieties analyzed were selected by W. G. Schmid to represent the major subgenera, sections and groups in the genus Hosta.

\section{Materials and Methods}

Plant material. The 37 accessions selected and their current classification is listed in Table 1. W.G. Schmid selected these accessions from his personal collection that he maintains in Tucker, Ga. Young leaves were detached from mature plants, wrapped in moist paper towels hostas. In addition, the boundaries between taxa and sent overnight to Tennessee State University, Nashville. Upon arrival, leaves were washed in deionized water, frozen in liquid nitrogen and stored at $-70{ }^{\circ} \mathrm{C}$ until used.

DNA extraction. Genomic DNA isolation was carried out according to the method of Ling et al, 1997. Leaf tissues ( $0.5 \mathrm{~g})$ were homogenized in the lysis buffer supplied with the Nucleocon Phytopure PlantDNAExtraction Kit (Vector Laboratories, Inc, CA) and incubated at $65^{\circ} \mathrm{C}$ for $10 \mathrm{~min}$. DNA extractions were carried out by adding chloroform and DNA extraction silica suspension, and centrifuged at 13,000 g for $10 \mathrm{~min}$. The DNA in the water phase was precipitated in isopropanol and dissolved in TE buffer.

RAPD procedure. RAPD was carried out following the protocol provided by Operon Technologies (Alameda, Calif.) for Random Primer Kit B. Twenty RAPD PCR Primers from Kit $\mathrm{B}$ were used. Primers included OPB-01 (5'-GTTTCGCTCC-3'); OPB-02 (5'-TGATCCCTGG-3'); OPB-03 (5'CATCCCCCTG-3'); OPB-04 (5'-GGACTGGAGT-3'); OPB-05 (5'-TGCGCCCTTC-3'); OPB-06 (5'-TGCTCTGCCC-3'); OPB-07 (5'-GGTGACGCAG-3'); OPB-08(5'-GTCCACACGG-3'); OPB-09(5'-TGGGGGACTC-3'); OPB-10 (5'-CTGCTGGGAC-3'); OPB-11 (5'GTAGACCCGT-3'); OPB-12 (5'-CCTTGACGCA-3'); OPB-13 (5'-TTCCCCCGCT-3'); OPB-14 (5'-TCCGCTCTGG-3'); OPB-15 (5'GGAGGGTGTT-3'), OPB-16(5'-TTTGCCCGGA-3'); OPB-17 (5'-AGGGAACGAG -3'), OPB-18 (5'-CCACAGCAGT-3'); OPB-19 (5'ACCCCCGAAG-3'); OPB-20 (5'-GGACCCTTAC-3'). PCR reaction mixtures contained 20 ng genomic DNA, 1× PCR Buffer B/II (100 mM KCL, 100 mM Tris-HCl, pH 8.3), 1.2 mM $\mathrm{MgCl}_{2}, 200 \mu \mathrm{M}$ dNTPs, $0.2 \mu \mathrm{M}$ primer and 0.5 units of Taq polymerase. Amplifications were performed in a PTC-100 programmable thermal controller. The thermal cycle was $80^{\circ} \mathrm{C}$ for 15 min followed by 44 cycles of $94^{\circ} \mathrm{C}$ for $2 \mathrm{~min}$, $35^{\circ} \mathrm{C}$ for $1 \mathrm{~min}$, and $72{ }^{\circ} \mathrm{C}$ for $1 \mathrm{~min}$. The last extension step was $72{ }^{\circ} \mathrm{C}$ for $10 \mathrm{~min}$. At the termination of all PCR reactions, $20 \mu \mathrm{L}$ from each product was separated in $2.0 \%$ agarose gels. Gels were stained in ethidium bromide solution and photographed under UV light.

For data analysis, the images were converted to a numerical database using the RFLP Scan program. RAPD DNA marker bands were scored for their presence (1) or absence (0). The data was converted into a diagrammatic representation of banding patterns. The phylogenetic relationships among the 37 hosta accessions was determined using Phylogeny Inference Package by Phylip.

\section{Results and Discussion}

Primer selections and the effect on RAPD banding patterns. All primers generated RAPD markers for all accessions evaluated. Some genotypes generated unique DNAmarker bands that allowed them to be easily distinguished from other members of a section with a single primer while others required several primers to obtain sufficient polymorphic band combinations. Figure 1 shows that primer OPB-12 (5'- 
Subgenus Hosta

H. plantaginea

Subgenus Giboshi

Group I and Group II

Section Helipteroides

H. montana

H. montana f. macrophylla

H. nigrescens

H. sieboldiana

Section Rynchophorae

H. kikutii 'Kikutii'

H. kikutii 'Caput-Avis'

H. kikutii 'Polyneuron'

H. kikutii 'Yakusimensis'

H. kikutii 'Densa'

Group III

Subgenus Bryocles

Section Eubryocles

H. ventricosa
Section Nipponosta

(Central and Northern Japan)

H. ibukiensis
Section Intermediae

H. densa

H. pachyscapa

Section Nipponosta

(Central Japan)

H. rectifolia
Section Picnolepis

H. aequinoctiiantha H. hypoleuca

H. longipes 'Urajiro' $H$. longipes f. latifolia

H. okamotoi

H. pycnophylla

H. rupifraga

H. takiensis

Section Nipponosta

(Japan, Tsushima Island,

Southern insular Korea,

Northeastern China)

H. longissima

H. takahashii

H. tardiva

H. tibae

H. tsushimensis
CCTTGACGCA-3') produced one marker band ( $850 \mathrm{bp}$ ) for $\mathrm{H}$. densa and two different ones (981 and 644 bp) for $H$. pachyscapa. These bands allowed for the differentiation of $H$. densa and $H$. pachyscapa using a single primer (Fig. 1A).

Members of section Nipponosta of subgenus Giboshi Group III ( $H$. tardiva, H. takahashii, H. tibae and $H$. tsushimensis 'Ogon') were compared using a single primer OPB-01 (5'GTTTCGCTCC-3'), generated three bands (Fig. 1B). The polymorphic band ( $850 \mathrm{bp}$ ) common to H. tardiva, H. takahashii, H. tibae allowed for the separation of $H$. tsushimensis from the group. The second band (937 bp), which was common to $H$. tardiva and $H$. tibae allowed for their

Fig. 1. DNA banding profiles of Hosta species that can be differentiated using one RAPD primers. A- PrimerOPB-12 (5'-CCTTGACGCA-3'); BPrimer-OPB-01(5'-GTTTCGCTCC3'); C-Primer-OPB-04 (5'-GGACTGGAGT-3'); D- Primer-OPB-02 (5'-TGATCCCTGG-3'); E-PrimerOPB-02 (5'-TGATCCCTGG-3'); F-Primer-OPB-17 (5'-AGGGAACGAG-3') 3-H. venusta; 4-H. minor; 5-H. capitata; 6-H. nankaiana; 10-H. montana; $11-H$. montana $\mathrm{f}$. macrophylla; $12-H$. seiboldiana; 15-H. nigrescens; $18-H$. densa; $19-H$. pachyscapa; 20-H. kikutii 'Kikutii', 22-H. kikutii 'Caput-Avis'; 23-H. kikutii 'Polyneuron'; 24-H. kikutii 'Yakusimensis'; 29-H. aequinocitiiantha; 30-H. hypoleuca; 31-H. okamotoi; 33-H. pycnophylla; 34-H. rupifraga; 35-H. takiensis; 36-H. tardiva; 39-H. takahashii; 40-H. tibae; 41-H. tsusimensis 'Ogon'.
Section Lamellatae

H. capitata

H. nakaiana

$H$. venusta

H. minor

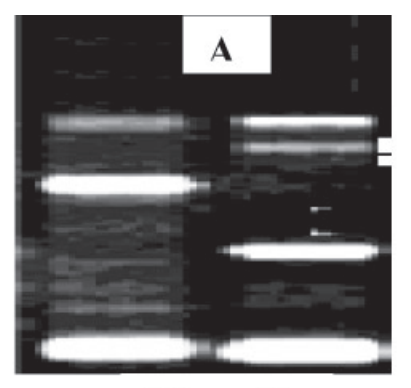

$18 \quad 19$

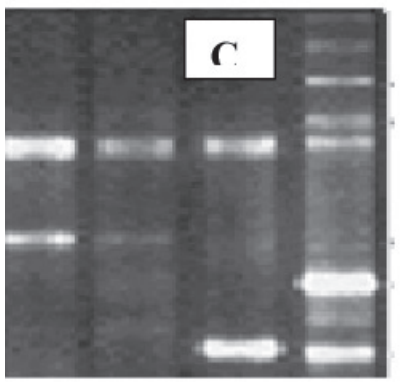

$\begin{array}{llll}3 & 4 & 5 & 6\end{array}$
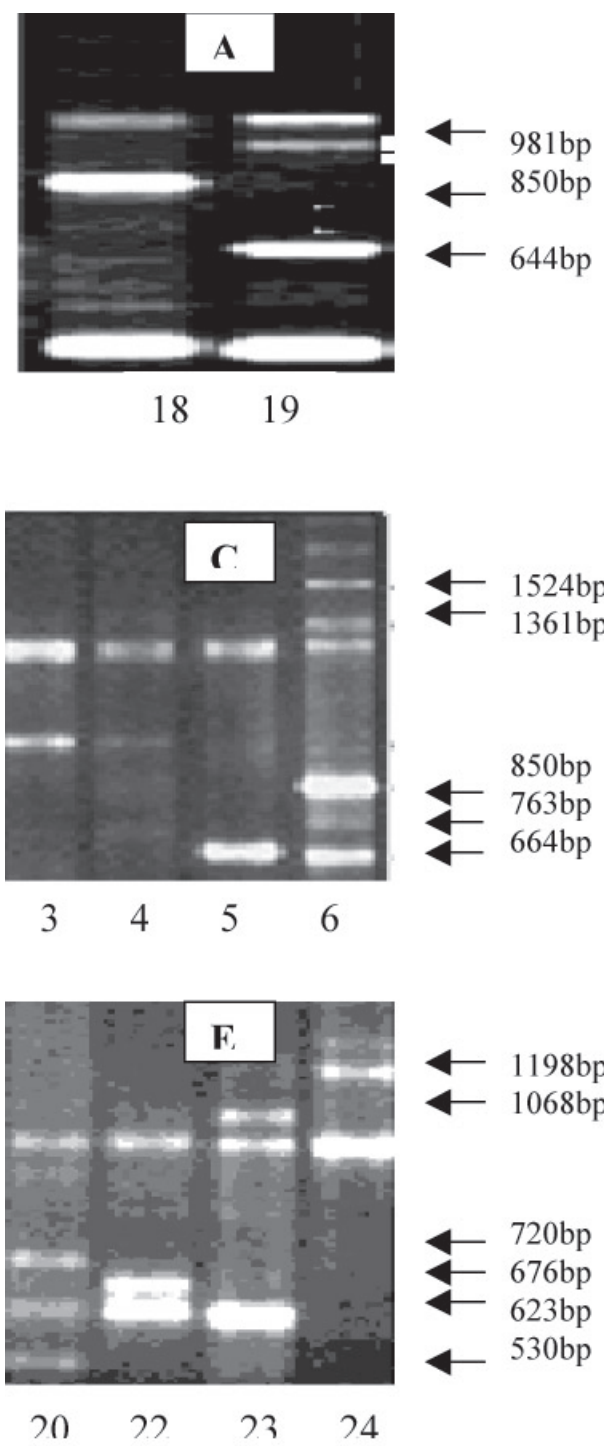
$1361 \mathrm{bp}$

850bp $763 \mathrm{bp}$ $664 \mathrm{bp}$
Section Arachnanthae

H. laevigata
$1524 b p$

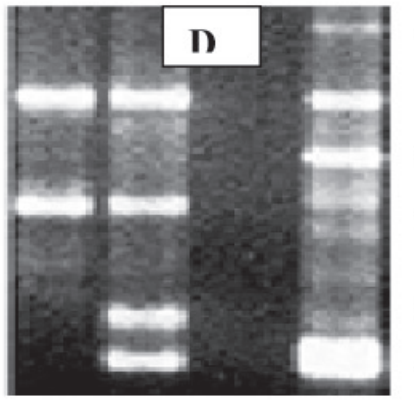

$\begin{array}{llll}10 & 11 & 12 & 15\end{array}$
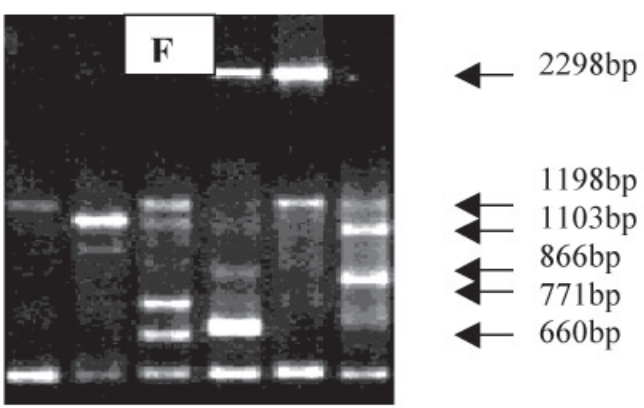

$\begin{array}{llllll}29 & 30 & 31 & 33 & 34 & 35\end{array}$ 


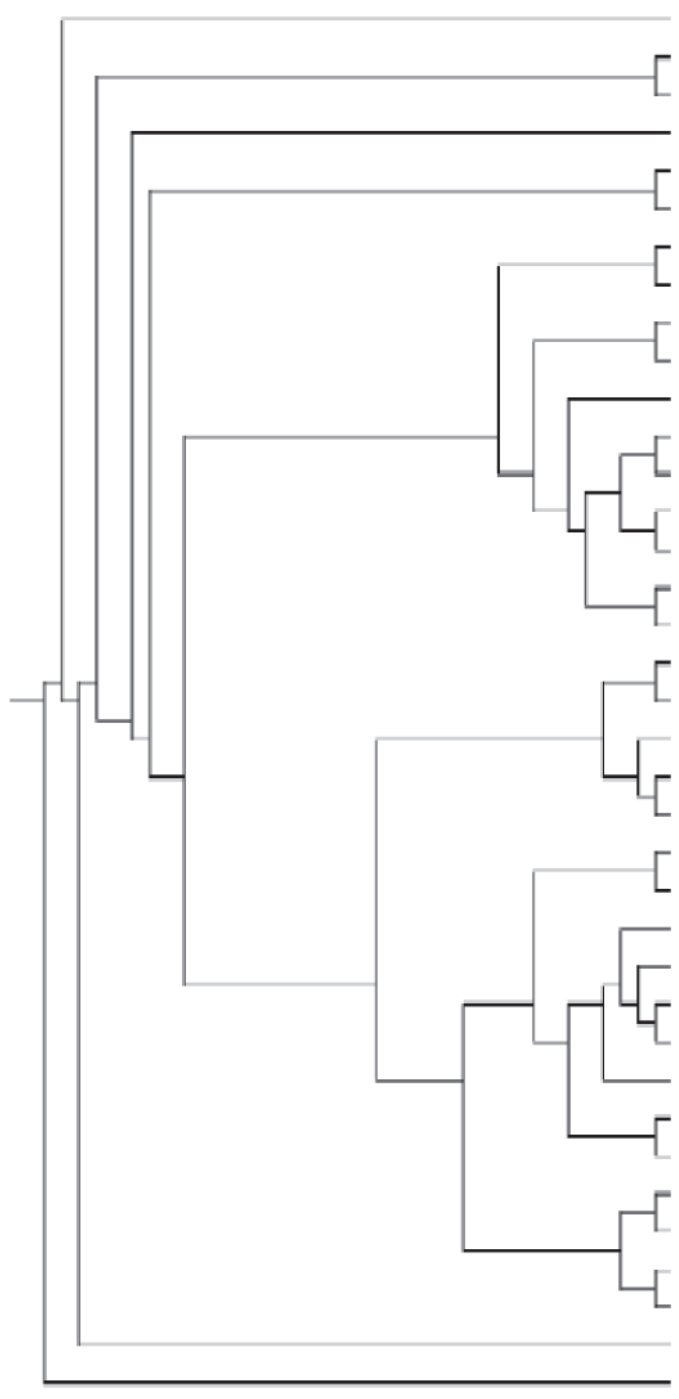

H. nakaiana

H. kikutii 'Densa'

H. minor

H. 'Amanuma'

H. rupifraga

H. aequinoctiiantha

H. takiensis

H. densa

H. okamotoi

H. hypoleuca

H. longipes f. latifolia

H. kikutii 'Caput-Avis'

H. pachyscapa

H. kikutii 'Yakusimensis'

H. nigrescens

H. kikutii.'Polyneuron'

H. capitata

H. ibukiensis

H. longipes 'Urajiro'

H. pycnophylla $\times$ H. longipes $\mathrm{f}$. latifolia

H. seiboldiana

H. laevigata

H. 'Undulata'

H. takahashii

H. rectifolia 'Rectifolia'

H. 'Allan P. McConnell'

H. longissima 'Longifolia'

H. kikutii 'Kikutii'

H. montana f. macrophylla

H. tibae

H. montana

H. tsushimensis 'Ogon'

H. pycnophylla

H. tardiva

H. venusta

H. ventricosa

H. plantaginea

Fig. 2. Cluster analysis of RAPD data using the phylogeny inference package (PHYLIP). The dedrogram illustrates the genetic relationships among 37 hosta accessions based on RAPD analysis.

separation from H. takahashii. The third band (676 bp) allowed for the separation of $H$. tibae from $H$. tardiva.

Other species that were distinguished with only one primer include members of the Lamellatae section (subgenus Bryocles) with OPB-04 (5'-GGACTGGAGT-3')(Fig. 1C), members of section Helipteroides (subgenus Giboshi) with primer OPB-02 (5'-TGATCCCTGG-3') (Fig. 1D), members of the subgenus Giboshi with primer OPB-02 (5'-TGATCCCTGG-3') (Fig. $1 \mathrm{E})$; and members in the section Picnolepis of the subgenus Giboshi with primer OPB-17 (5'-AGGGAACGAG -3') (Fig. 1F).

Phylogenetic relationship of hosta accessions based on RAPD analysis. Figure 2 shows the genetic distance among the 37 accessions that were evaluated in the study. According to cluster data analysis, $H$. plantaginea was the most genetically distinct species. Hosta plantaginea, the only night-blooming member of the genus, was placed in its own subgenus because of this unique characteristic (Schmid, 1991). RAPD analysis supported this separation.

Species in the subgenus Bryocles are very diverse, with genetical and phenotypical differences. For example, $H$. ventricosa is a tetraploid. RAPD analysis confirmed this distinction (Fig. 2) and supports the separation of this species in its own section (Eubryocles). In the Revised Systematic Listing and Graphic Keys, Schmid (1991) placed $H$. venusta, $H$. minor, $H$. capitata, and $H$. nakaiana under the section Lamellatae of the subgenus because they were collected in the same geographical region. But, because these species were different from each other, he felt that they were not related. Cluster analysis of RAPD data supports his suspicion; they have very low genetic similarity among each other. The lack of genetic similarity among these species indicates that they may not have evolved from that location; they may have been brought in from other areas. RAPD analysis indicated two species (H. nakaiana and $H$. capitata,) believed to be sports of each other since they share many phenotypic characteristics, (Fujita, 1976; Maekawa 1969), are actually genetically very different. In the subgenus Giboshi, Group III, all accessions were separated into two closely linked clusters. Two U.S. accessions,
H. rectifolia and $H$. longissima, and four taxa collected in Japan, Tsushima Island, southern Insular Korea, and northeastern China $(H$. tardiva, H. takahashii, H. ibukiensis, H. tsushimensis 'Ogon') all belong to the same cluster. These plants are genetically related and share high morphological similarities.

Many hosta varieties and cultivars have resulted from natural interspecific hybridization. RAPD analyses showed that the hybrid $H$. pycnophylla $\times$ H. longipes $\mathrm{f}$. latifolia shared more genetic similarity to $H$. pycnophylla, suggesting that $H$. pycnophylla is the maternal parent of H. longipes f. latifolia.

Fujita (1976) believed that $H$. rupifraga and H. longipes f. latifolia were the same. However, Maekawa (1940) thought that they should be classified differently because the flower scapes of $H$. longipes $\mathrm{f}$. latifolia are longer than those of $H$. rupifraga (which are more broadly ovated). RAPD results support the rationale of Maekawa; the two species are genetically distinct and should remain separated.

This study demonstrates the use of RAPD markers for estimating the genetic variation that exists among a population of different hostas.

\section{Literature Cited}

Bielawski, J.P., K. Noack, and D.E. Pumo. 1995. Reproducible amplification of RAPD markers from vertebrate DNA. Biotechniques 18:856-860.

Grenfell, D. 1996. The gardener's guide to growing hostas. Timber Press, Portland, Ore.

Ling, J-T., R.J. Sauve, and N. Gawel. 1997. Identification of poinsettia cultivars using RAPD markers. HortScience 32:122-124.

Lin, J-J., J. Kuo, J.A. Saunders, M. MacDonald, H. Beard, and B.F. Matthews. 1995. Determination of soybean DNA polymorphisms using different DNA fingerprinting techniques. Plant Genome IV Conference, San Diego, Calif.

Maekawa. 1940. The genus Hosta. Amer. Hosta Soc. Bul. [1972] 4:12-64 and [1973] 5:12-59.

Maekawa. 1969. Hosta trattinnick, p. 1104-1109. vol 3. In: The encyclopedia of horticulture. Seibundoshinkosha, Tokyo.

Fujita, N. 1976. The genus Hosta in Japan. Amer. Hosta Soc. Bul. [1979] 10:14-43; 28:3-4, 151-153.

Gawel, N.J., G.R. Johnson, and R.J. Sauve. 1996. Identification of genetic diversity among Loropetalum Chinese 'Rubrum' introductions. J. Environ. Hort. 14:38-41.

Ling, J-T., R.J. Sauve, and N. Gawel. 1997. Identification of poinsettia cultivars using RAPD markers. HortScience 32:122-124.

Schmid, W.G. 1991. The genus Hosta. Timber press, Ore.

Weising, K. and G. Kahl 1990. DNA fingerprinting in plants-The method. BFE 7 (3)

Zonneveld, B.J.M. and I.F. Van. (2001) Genome size and pollen viability as taxonomic criteria: application to the genus Hosta. Plant Biol. 3:176-185.

Zonneveld, B.J.M. 1997. Cultivar and cultivar-group definitions applied to Hosta. Amer. Hosta Soc. Bul. 28:37-41.

Zonneveld, B.J.M. (1998) Hosta "Crispula" is not an "Undulata". Brit. Hosta and Hemerocallis Bul. 4:64-65.

Zhou, S. and R.J. Sauve. 2002. Use of fluorescentamplified fragment length polymorphism for species identification in the genus Pulmonaria. J. Environ. Hort. 20:110-113. 